\title{
Bioterrorism and smallpox planning: information and voluntary vaccination
}

\section{J Selgelid}

Both public and private deliberation on the question of smallpox vaccination require information disclosure by the intelligence community

\section{Abstract}

Although smallpox was declared eradicated in 1980, there are fears that stocks of the virus manufactured for military purposes by the Soviet Union may have fallen into the hands of "rogue nations" or terrorists. Worries about bioterrorism have thus sparked debate about whether or not the smallpox vaccine, which can be dangerous, should be offered to the general public. Meaningful public debate on this issue requires expert information about the likelihood that the virus will in fact be used as a weapon. Informed voluntary individual decision making, about whether to get vaccinated if vaccine is made available to the public, would similarly require appreciation of the likelihood of attack. Public deliberation and private deliberation thus both require briefing by the intelligence community.

\section{SMALLPOX, PAST AND PRESENT}

The US government's preparation for a possible bioterrorist smallpox attack received high profile American newspaper attention during 2002 and early 2003. While the weaponisation of smallpox raises a number of ethical issues, a central concern is the question of who should be vaccinated in the "preattack" scenario. ${ }^{1}$

Often considered the most dreaded human disease, smallpox killed more people than the plague or any other infectious disease. ${ }^{2}$ During the 20th century alone it killed between 300 and 540 million people, which is more than were killed by "all the wars and epidemics" of that period. ${ }^{3}$

Following heroic global vaccination efforts, the last (reported) "natural occurring" case of the disease occurred in Somalia in 1977. The World Health Organization (WHO) officially declared smallpox eradicated in 1980. This is a great success story of medicine.

Upon eradication it was agreed that all remaining samples of the smallpox virus, called variola, be kept under tight security at two facilities: the Centers for Disease Control and Prevention, in Atlanta, and the Ivanovsky Institute of Virology, in Moscow. It has recently been revealed, however, that the Soviet Union manufactured and stored tens of tons of smallpox for military purposes until its fall in the early 1990s. ${ }^{4}$ American scientists and government officials now worry that the massive military supply of Soviet smallpox was insufficiently guarded and that the virus may have fallen into dangerous hands.

Another concern is that "rogue nations" may have saved their own secret stocks of smallpox all along. According to the Washington Post, a leaked classified American intelligence review says as much and also "that Osama bin Laden devoted money and personnel to pursue smallpox, among other biological weapons" ${ }^{\prime .}{ }^{5}$ If smallpox is used as a weapon the effects could be catastrophic. Much of the world's population has never been vaccinated, and the immunity of those who were vaccinated decades ago is expected to have worn off. The disease is highly contagious and kills one in three of its victims. Experts warn that a bioterrorist attack could trigger a global epidemic. ${ }^{6}$

Preparing for possible attack, the United States has been building a supply of vaccine and planning its distribution. On September 11th 2001, the US had only 15 million doses of vaccine. It has since acquired an additional 85 million doses found frozen, and donated, by a pharmaceutical company. ${ }^{7}$ Because the vaccine can be diluted, it is believed that there is now enough on hand to protect the entire American population in case of an emergency. Additional new doses have in the meantime been ordered. ${ }^{7}$ Although Britain, Germany, Israel, and
South Africa are also thought to have substantial stocks of vaccine, the extent of supply in most other countries is poorly publicised and likely to be low.

The immediate American "preattack" plan is to vaccinate 500000 domestic health care and emergency workers and 500000 military personnel. Following this initial phase, the vaccine will be offered to an additional 10 million health care and emergency workers. "Ring" vaccination of contacts-or perhaps "mass" vaccination of entire regions-is likely if attack occurs. It is questionable, however, whether vaccine should be made available to the general public on a voluntary basis in the preattack scenario. Public debate on this matter has been encouraged. Quarantine policy is also the subject of controversy.

The smallpox vaccine involves a "live" virus, called vaccinia. Of all vaccines, it has one of the highest rates of complications-including death, disability, scarring, and minor morbidity. ${ }^{8}$ Hence the discontinuation of routine vaccination when eradication was accomplished. "For every million people vaccinated, 1000 may have serious reactions, 14 to 52 people will suffer life threatening illnesses and one or two could die", according to federal officials. ${ }^{10}$ Some complications are treatable with VIG (vaccinia immune globulin), but this is currently in short supply.

The site of smallpox vaccination, furthermore, can cause (sometimes deadly) infection to third parties for 2 to 3 weeks after inoculation. Persons with skin disorders (such as eczema), pregnant women, and those with weakened immune systems-as a result of AIDS, organ transplant therapy, or cancer treatment-are especially vulnerable to infection from their own or other people's vaccinations. Compared to 30 years ago, many more people now have eczema and weakened immune systems. Recent evidence suggests that vaccination might also contribute to heart disease: seven health workers "developed cardiac problems after being vaccinated as part of the [American] government's [current] program", and two of these died. Vaccination of those with known heart disease has thus been suspended, and experts recommend that those with "three or more major risk factors-like smoking, diabetes, high blood pressure or high cholesterol—also be excluded". ${ }^{11}$

Some people think that vaccination of the general public prior to attack would cause unnecessary mortality. "Public health authorities in and out of government project that the vaccine itself, widely administered, could kill more Americans-300 is a common estimate, 
and some are higher-than any terrorist attack save that of September 11 , $2001^{\prime \prime} .{ }^{5}$ Opponents to general availability argue that the mere possibility of a smallpox attack does not warrant policy that would lead to the certain death of so many people.

Those who favour offering vaccine to the general public, on the other hand, argue that "61 per cent of Americans would want to be vaccinated if smallpox vaccine were available, and the public thus appears to be ready for this approach". ${ }^{12}$ In addition to arguing that individuals should be allowed to weigh risks and benefits themselves, and make their own choices as they see fit, proponents argue that a virtue of making vaccine available to the public ahead of time is that this could actually deter a bioterrorist smallpox attack to begin with: the larger the number of people vaccinated in advance, the less effective an attack would be.

Controversy is complicated by the fact that the Food and Drug Administration (FDA) classifies much of the existing vaccine, because of its age and dilution, as "investigational". Ordinary citizens who are vaccinated, and perhaps third parties exposed to them, would in effect be experimental subjects. Would, or could, informed consent be obtained from the latter?

\section{PUBLIC DEBATE AND INDIVIDUAL DECISION MAKING REQUIRE DISCLOSURE OF POTENTIALLY SENSITIVE INFORMATION}

The question of whether or not smallpox vaccine should be made available to the general public in the "preattack" scenario would be more easily settled if we knew how likely it is that smallpox will be used as a weapon. If chances are high that attack will occur, then more people should be vaccinated ahead of time to prevent the large scale death and chaos expected in a population lacking immunity. From a societal standpoint, the mortality and morbidity of vaccination would be an acceptable cost of forestalling catastrophe. The side effects of vaccination were generally accepted, after all, when naturally occurring smallpox was a danger. The fact that some would suffer from complications of vaccination, although unfortunate, would be less worrisome if the risks were voluntarily accepted by informed individuals.

If attack is extremely unlikely, on the other hand, then vaccinating the public may cause sickness and death for no good reason. If the probability of attack is almost zero, or merely theoretical, then vaccination of the general public (or at least those who choose to be vaccinated) would have costs but no benefits. Many would die as a result of vaccination, but none would be saved by vaccination if attack was never forthcoming.

Meaningful public debate about vaccination policy thus requires information about the likelihood of attack. What countries (or groups) have access to the virus-for example-and what are their intentions? If exact knowledge of such things is impossible, then it would be useful to hear about ranges of probabilities (which I assume are used by intelligence experts) or, at least, the evidence there is for thinking that such and such countries (or groups) have access to the virus, and the evidence there is for thinking that such and such countries' (or groups') intentions are $\mathrm{X}$ rather than Y. To the extent that this kind of information is secret, the public debate encouraged by Anthony Fauci ${ }^{13}$ will suffer.

Important information is already available in the public domain-in newspaper articles about leaked classified intelligence reports, ${ }^{5}$ in Ken Alibek's confessions about the Soviet weapons programme, ${ }^{4}$ and in a number of other recently published popular science thrillers. ${ }^{14}$ My educated guess, however, is that military and intelligence authorities have refrained from revealing significant relevant information. Evidence of this likelihood is illustrated by precedent. Although American intelligence experts were briefed by high ranking defectors (Vladimir Pasechnik and Ken Alibek) from the Soviet biological weapons programme as early as 1989 and 1992 (respectively), for example, even D A Henderson (who led the WHO eradication campaign and advised the US government on matters related to smallpox) was kept in the dark until $1996 .^{2}$ Although lacking information that most would consider crucial to the debate, Henderson had in the meantime been arguing for destruction of smallpox samples. Although he, and many other scientists, continued to argue for the destruction of official stocks of the virus long after learning about the Soviet programme, debate prior to the briefing of Henderson and other scientists was compromised by information withholding. The general public-and many governmental officials-remained uninformed about the Soviet bioweapons programme until 1998 when Alibek himself went public. ${ }^{2}$

One should not expect intelligence agencies to reveal all that is known about the danger of smallpox attack. Public disclosure of sensitive information about the possessions and intentions of potentially hostile groups and countries could jeopardise national security in numerous ways. A balance should be struck, however, between the maximal promotion of security, on the one hand, and the facilitation of (scientific and) democratic debate and decision making, on the other.

Some might deny that much additional information about the likelihood of attack is necessary for solution to controversy about whether smallpox vaccine should be made available to the public on a voluntary basis. Even if lives are unnecessarily lost as a result of vaccinating anyone who wants to be vaccinated, one might argue, the decision of whether to vaccinate should be left in the hands of individuals informed about potential risks and benefits. The idea is that individuals should be free to make their own choices according to their own risk taking strategies.

Even if this is correct, disclosure of information remains important. One cannot make an informed choice of vaccination over no vaccination, or vice versa, unless aware of both the risks of vaccination and the risks of remaining unvaccinated. The risk of remaining unvaccinated is poorly understood to the degree that one is unaware of the likelihood of attack, the likelihood that one would be infected in the event of an attack, and the likelihood that one would die (or be blinded or scarred) if infected. Informed voluntary decision making involves awareness of realities and probabilities. The ideal of informed voluntary decision making therefore requires that anyone offered the choice of vaccination versus no vaccination directly receive explicit explanations (in consultation and perhaps through consent forms).

Suppose that the best intelligence indicates that the risk of attack is extremely low and that the chance of any given individual becoming infected with smallpox is lower than the chance of dying from vaccination. If unaware of these details, many would presumably choose vaccination, despite the fact that they would have considered this irrational and chosen otherwise if they had been informed. Suppose modelling shows there would need to be at least a $10 \%$ chance of attack for it to be in the average American's self interest to risk vaccination and that intelligence experts believe the risk of attack is actually much lower than this. This kind of information should be shared with those offered vaccine if the importance of individual decision making is supposed to provide the rationale behind general availability of vaccination.

Imagine, on the other hand, that the risk of attack was fairly high and that this was not made public for security reasons. Many, who would have chosen vaccination if aware of the risk of 
attack, would remain unvaccinated. If attack ensues then the deaths of those who only remained unvaccinated because they were deprived of information will lead to complaints similar to those raised about what might have been known, but was not revealed, by the American intelligence community prior to September 11th-that is, if it was known in advance that it would be dangerous to enter the World Trade Center that day, then people should have been warned. My purpose is not here to claim that such information was in fact withheld prior to September 11 . My point is to illustrate the kind of complaint to be expected if individuals are deprived of information essential to their own personal security.

\section{ACKNOWLEDGEMENTS}

Research support provided by (1) the Research Office and the Faculty of Health Sciences' Division of Bioethics at the University of the Witwatersrand, Johannesburg, South Africa, and (2) the Fundacion Seneca and the Philosophy
Department of the University of Murcia, Murcia, Spain.

$J$ Med Ethics 2004;30:558-560.

doi: 10.1136/jme.2003.004176

Correspondence to: M J Selgelid, Centre for Values, Ethics and the Law in Medicine (D06), and Unit for History and Philosophy of Science (F07), The University of Sydney, NSW, 2006, Australia; selgelid@med.usyd.edu.au

Received 31 March 2003

Accepted for publication 30 May 2003

\section{REFERENCES}

1 Selgelid MJ. Smallpox revisited? Am J Bioeth 2003:3:W5-W1 1, http://bioethics.net/journal/ infocus/pdf/3_1_IF_w05_Selgelid.pdf (accessed 24 Aug 2004).

2 Tucker JB. Scourge: the once and future threat of smallpox. New York: Grove Press, 2001.

3 Miller J, Engelberg S, Broad W. Germs: the ultimate weapon. London: Simon and Schuster, 2001:58.

4 Alibek K. Biohazard. New York: Random House, 1999.

5 Gellman B. Four nations thought to possess smallpox. The Washington Post, 2002 Nov 5 http://www.washingtonpost.com/ac2/wpdyn? pagename $=$ article\&contentld $=$ A51 13 2002Nov4 (accessed 24 Aug 2004).
6 Broad WJ. US acts to make vaccines and drugs against smallpox. The New York Times on the Web, 2001 Oct 9 http://www.nytimes.com/ 2001/10/09/health/anatomy/09SMAL.html (accessed 24 Aug 2004)

7 Gillis J. Of terrorists and mosquitoes. The Washington Post, 2002 Nov 5 http:// washingtonpost.com/ac2/wp-dyn/A54382002Nov4? language $=$ printer $($ accessed 24 Aug 2004).

8 Engler RJ, Kenner J, Leung DY. Smallpox vaccination: risk considerations for patients with atopic dermatitis. J Allergy Clin Immunol 2002; 110:357-65.

9 Henderson DA, Inglesby TV, O'Toole T, eds. Smallpox as a biological weapon in bioterrorism: guidelines for medical and public health management. Chicago, IL: American Medical Association Press, 2002:113-15.

10 Pear R. Congress is asked to compensate those harmed by smallpox vaccine. The New York Times on the Web, 2003 Mar 6 http:// www.nytimes.com/2003/03/06/health/ 06CND-SMALL.html (accessed 24 Aug 2004).

11 Grady D. Exclude more from smallpox vaccinations, US is urged. The New York Times on the Web, 2003 March 29 http:// www.nytimes.com/2003/03/29/international/ worldspecial/29SMAL.html (accessed 24 Aug 2004).

12 Bicknell WJ. The case for voluntary smallpox vaccination. N Engl J Med 2002;346:1323-5.

13 Fauci AS. Smallpox vaccination policy-the need for dialogue. N Engl J Med 2002;346: 1319-20.

14 Preston R. The demon in the freezer. New York: Random House, 2002 